\title{
Liver Metastasis of Malignant Pilomatrixoma: Devastating Outcome from A Possibly Under-Treated Case
}

\author{
Flora Dameria*, Marini Stephanie ${ }^{* *}$, Ening Krisnuhoni**, Diah Rini Handjari**, \\ Nur Rahadiani** \\ *Department of Anatomical Pathology Residency Program, Faculty of Medicine \\ Universitas Indonesia/Dr. Cipto Mangunkusumo General National Hospital, Jakarta \\ ** Division of Gastroentero-hepatobilliary Pathology, Department of Anatomical Pathology \\ Faculty of Medicine, Universitas Indonesia/Dr. Cipto Mangunkusumo General National Hospital, Jakarta
}

\begin{abstract}
Corresponding author:
Nur Rahadiani. Division of Gastroentero-hepatobilliary Pathology, Department of Anatomical Pathology, Dr. Cipto Mangunkusumo General National Hospital. Jl. Diponegoro No. 71 Jakarta Indonesia. Phone: +62-2131930487; facsimile: +62-21-31934465.E-mail: nur.rahadiani@ui.ac.id
\end{abstract}

\begin{abstract}
Malignant of pilomatrixoma, known as pilomatrix carcinoma, is a rare cutaneous adnexal tumor that derives from hair matrix cells. The tumor usually occurs in male, with the predominant age range between 40 to 60 years old, located in the head and neck area. The tumor consisted of atypical basaloid cells aggregation, ghost cells, and keratinous material. We report a case of 54 years old male patient referred to Cipto Mangunkusumo Hospital Jakarta with a mass in his right upper quadrant abdomen and a lump in the axilla. The magnitude resonance imaging (MRI) and positron emission tomography (PET)-scan revealed metastatic lesions in several lymph nodes and internal organs. The patient underwent liver biopsy which showed that tumor was composed of atypical basaloid cells, amyloid-like material, keratin mass, and was diagnosed as pilomatrix carcinoma. This case is being reported due to its rarity, potential pitfalls due to histologic similarity with several other entities, and to show the importance of histopathology examination in patient's treatment to prevent a devastating outcome.
\end{abstract}

Keywords: basaloid cells, cutaneous adnexal tumor, ghost cells, malignant pilomatrixoma, pilomatrix carcinoma, metastasis of malignant pilomatrixoma

\begin{abstract}
ABSTRAK
Pilomatrixoma malignan atau yang dikenal sebagai Karsinoma pilomatrix adalah tumor adneksa kulit yang berasal dari sel-sel matriks rambut. Tumor ini langka, umumnya dijumpai di daerah kepala dan leher pasien laki-laki usia antara 40 hingga 60 tahun. Jenis tumor ini tersusun oleh proliferasi sel-sel basaloid atipik, ghost cells, dan keratin. Pada artikel ini kami melaporkan kasus pasien seorang pria berusia 54 tahun yang dirujuk ke Rumah Sakit Cipto Mangunkusumo Jakarta dengan massa di perut kuadran kanan atas dan benjolan di ketiak. Magnitude resonance imaging (MRI) dan positron emission tomography (PET)-scan menunjukkan lesi metastasis di beberapa kelenjar getah bening dan organ internal. Biopsi hati pasien menunjukkan bahwa tumor terdiri dari kelompokan sel basaloid atipik, material seperti amiloid, massa keratin, dan didiagnosis sebagai Karsinoma Pilomatrix. Kasus ini dilaporkan karena kelangkaannya, potensi pitfall karena kesamaan gambaran histologi dengan beberapa entitas penyakit lain, dan untuk menunjukkan pentingnya pemeriksaan histopatologi dalam perawatan pasien untuk mencegah hasil yang mengecewakan.
\end{abstract}

Kata kunci: sel basaloid, tumor adneksa kulit, ghost cells, pilomatrixoma malignan, karsinoma pilomatrix, metastasis pilomatrixoma malignan 


\section{INTRODUCTION}

Malignant pilomatrixoma or pilomatrix carcinoma (PC) is a rare malignant cutaneous adnexal tumor that arises from hair/follicular matrix cells. Lopansri and Mihm introduced this diagnostic entity in $1980 .{ }^{1}$ It was predominantly found in male with male to female ratio of 3-5:1 and approximately occurs from 40 to 60 years old. ${ }^{1-2}$ The head and neck are the most frequent site of predilection. ${ }^{2-3}$

Malignant pilomatrixoma can arise de novo as pilomatrix carcinoma or as a transformation of a benign pilomatrixoma in which $\beta$-catenin and (WNT) pathways are significant in its pathogenesis. ${ }^{1,4}$ This tumor can be clinically presented as an asymptomatic, solitary, reddish, and firm nodule, varying from 0.5 to $20 \mathrm{~cm}$ and grows in the dermis or subcutaneous layer., 4 Histopathologically, the tumor is consisted of atypical basaloid cell proliferation, ghost cells, and keratinous material. ${ }^{1,2,5}$ Several tumor entities have similar histopathology features, namely benign pilomatrixoma, calcifying cystic of odontogenic tumor (CCOT), and calcifying epithelial odontogenic tumor (CEOT).

Half of the malignant pilomatrixoma cases develop local recurrence. ${ }^{1}$ Thus, wide excision with clear surgical margins should be the primary treatment of choice. It can also spread to the lymph nodes or the internal organs as metastasis. Radiotherapy is an excellent alternative to surgery, especially in cases which clear margins are not possible to be assessed. ${ }^{1}$ Chemotherapy has not proven to be effective. ${ }^{1-3}$

This particular case is reported due to its rarity, potential pitfalls due to histologic similarity with several others entities, and to show the importance of histopathology examination in patient management.

\section{CASE ILLUSTRATION}

Fifty-four years old male patient was referred to Cipto Mangunkusumo Hospital with a mass in his right upper quadrant abdomen as the chief complaint. His abdomen has been enlarged and painful for the last four months. He also complained of having a lump in his axilla which has been present for at least eight years. This lump has become a long-standing abscess for two years which produced pus and blood. Though it had always been treated, it never yet resolved. There was no trauma or chronic inflammation history which preceded the lump. He also complained of vomiting, nausea, epigastric pain, bloating, fever, and weakness. His weight had decreased $30 \mathrm{~kg}$ in 3 months. Difficulty and pain in urinating and decreasing flow or velocity of urine stream appeared since three months prior to hospital admission. His urine color was dark brown.

At the time of admission, the patient was compos mentis but looked quite ill. His body temperature was slightly increased, while the blood pressure, pulse, and respiratory rate were within the normal range. During physical examination, his skin and sclera showed minimal yellow discoloration. The abdomen looked swelled and tender on the right quadrant area. The liver was $4 \mathrm{~cm}$ below the rib arch and $5 \mathrm{~cm}$ below the processus xyphoideus. Undulation and shifting dullness were also found. The lump in the axilla was a solitary reddish mass, $3.5 \mathrm{~cm}$ in diameter, tender, and produced pus and blood. His face looked symmetrical and no mass was not found in the mandible, maxilla, or inside his oral cavity. He stated that he had a history of mass excision in his lower jaw skin area 20 years ago without mandibulectomy. Unfortunately, the histology examination of this biopsy was never performed. According to the patient's information, the excised lump was not tender but approximately the similar size with the one in the axilla now. At present, he had diabetes mellitus and treated with oral anti-diabetic medication. The patient had no medical history of hepatitis, hematemesis, hematochezia, melena, or change in defecation pattern. He denied the habits of drinking alcohol and using drugs. There was also no history of hepatitis in his family.

The laboratory examination showed a slight increase in leukocyte $(11,750 / \mathrm{ul})$, total, direct, and indirect bilirubin respectively $(1.25 \mathrm{mg} / \mathrm{dL}, 0.4 \mathrm{mg} / \mathrm{dL}$, and $0.41 \mathrm{mg} / \mathrm{dL}$ ), serum liver function, AST and ALT respectively (115 U/L, $40 \mathrm{U} / \mathrm{L})$, and also erythrocyte sedimentation rate $(90 \mathrm{~mm})$. The alpha fetoprotein (AFP) level was within the normal range $(2.6 \mathrm{ng} / \mathrm{ml})$ while $\mathrm{HbsAg}$ and anti HCV serology were not reactive. The chest X-ray examination revealed mild fibrosis in the lower right lobes of the lung. The abdominal ultrasound revealed hepatomegaly and benign prostate hypertrophy. The abdominal computed tomography (CT)-scan showed hepatomegaly with multiple solid masses in the liver, suggestive of metastatic lesions. Ascites, pleural effusion, and lymphadenopathy were not found. Abdominal magnetic resonance imaging (MRI) was not performed. Magnetic resonance imaging for upper extremity revealed multiple ovalshaped lesions in the left lateral side of the chest, left of the head to the neck of the humerus and left of the axillary subcutis. All were concluded as metastatic lesions and malignant lymphadenopathies (Figure 1). 


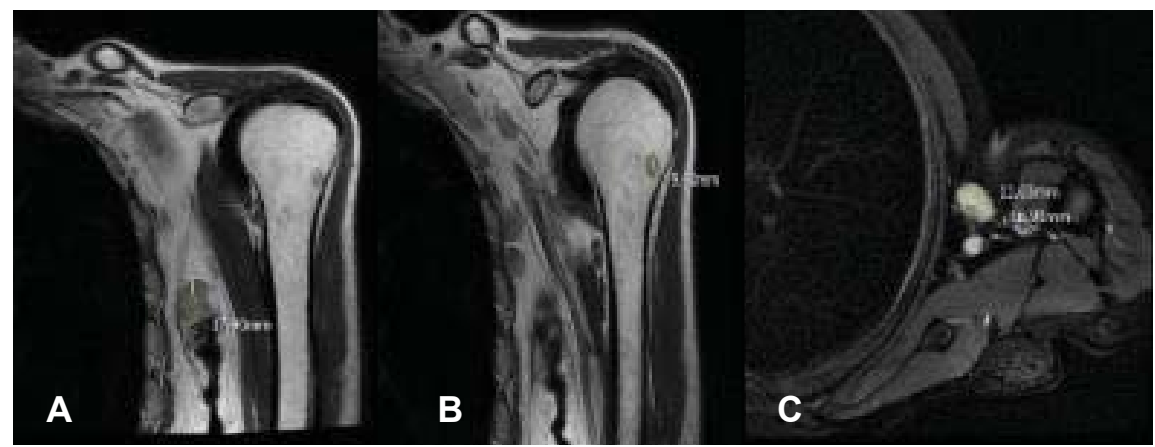

Figure 1. Upper extremity MRI showed multiple metastatic lesions and malignant lymphadenopathies in several locations; (A) left lateral side of the chest; (B) left of the head to the neck of the humerus; (C) axillary subcutis.
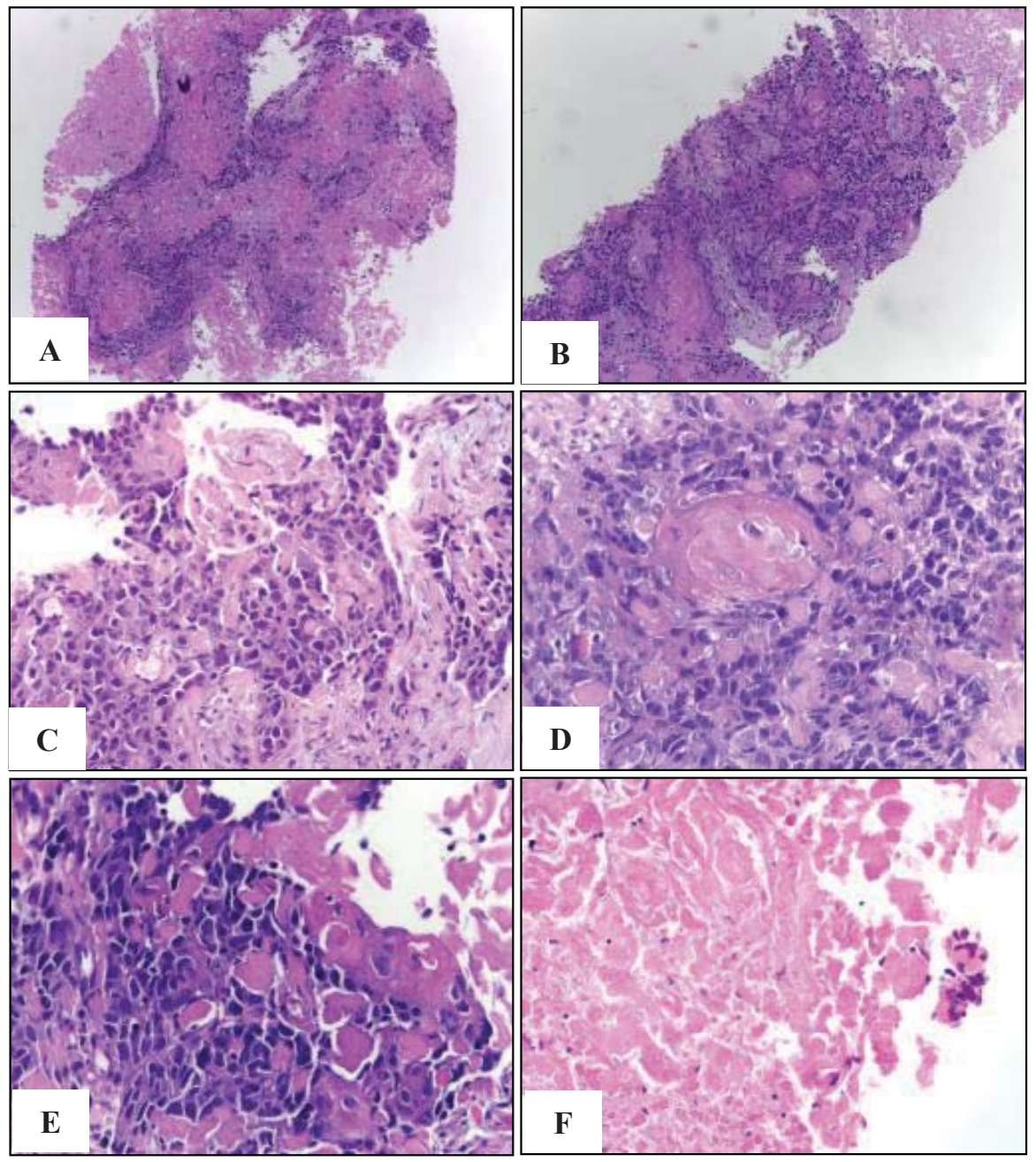

Figure 2. Core liver biopsy: (A-B) tumor cells consisted of atypical basaloid cells. No remaining normal liver tissue was identified (H\&E stain, A-B x100); (C) tumor cells with numerous atypical mitotic figures; (D-E) tumor cells with hyperchromatic nuclei, pleomorphic, prominent nucleoli, accompanied with amyloid-like, and keratin mass. (H\&E stain, $\mathrm{x400);} \mathrm{(F)} \mathrm{necrotic} \mathrm{area.} \mathrm{(H \& E} \mathrm{stain,} \mathrm{x400)}$ 

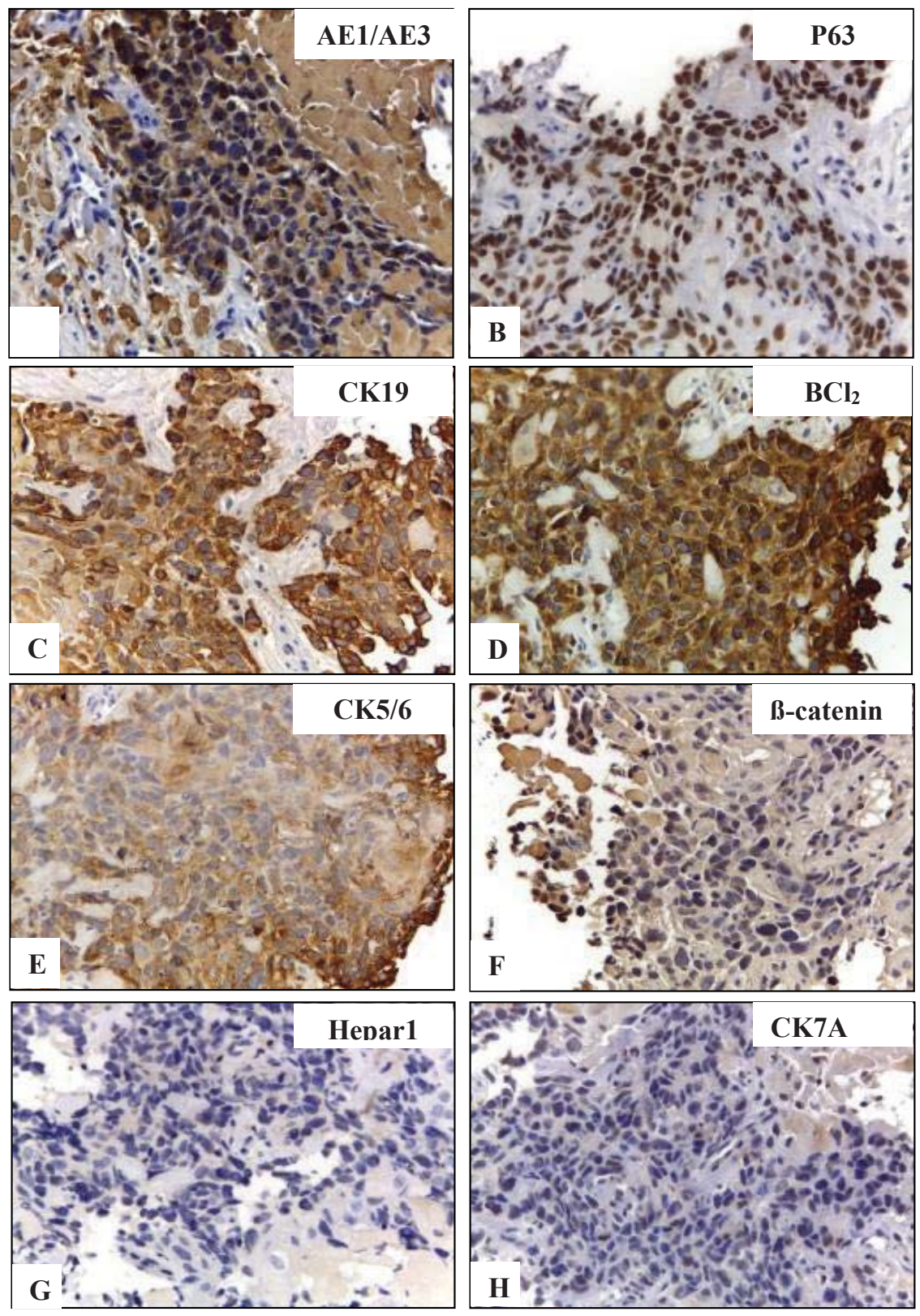

Figure 3. Immunohistochemistry staining in several antibodies (in X400): (A-E) positive staining; (F-H) negative staining.

The positron emission tomography (PET)-scan showed multiple hypermetabolic solid masses located in the anterior superior mediastinum, bilateral, and caudate lobes of the liver, the right parotid gland, the fourth left rib, and the caput of the left humerus. Multiple lymph nodes were also identified, including the bilateral cervical, bilateral axilla, mediastinal, perigastric, and left maxilla. All lesions were interpreted as metastatic lesions.

The histopathology from the liver biopsy consisted of entirely malignant epithelial tumor mass. The tumor was composed of aggregations of atypical basaloid cells, amyloid-like material, and keratin mass. The tumor cells were observed as polygonal cells with pleomorphic and hyperchromatic nuclei. Mitosis are high and atypical. There was no normal tissue can be identified (Figure 2). Immunohistochemistry showed positivity for AE1/AE3 and p63, negative for Hepar1 and CK7. Additional immunohistochemistry was performed and showed positivity for $\mathrm{CK} 19, \mathrm{BCl} 2$, and CK5/6, negative for ß-catenin (Figure 3). Meanwhile, the histochemistry stain, congo red, did not give birefringence appearance. The patient died 6 months after the first metastatic lesion was diagnosed. 


\section{DISCUSSION}

The patient in this case, should be assessed with working diagnosis of primary tumor (of the liver) versus secondary tumor. Hepatocellular carcinoma (HCC), the most common entity of primary liver tumor, should be listed as the most possible diagnosis. However, this patient denied having any history of prior liver disease and its risk factors, confirmed by negative serology for viral infection markers and low rate of AFP level. Moreover, the radiology examination also stated that the tumor was more likely was secondary than of a primary origin.

Many diseases can spread to the liver, such as colorectal and prostate cancer. The patient did not complain having bloody stools or diarrhea, as well as other complaints originating from prostate enlargement. Instead, this patient was complaining about his long standing lump in the axilla which produced blood and pus. This raised the suspicion of a possible primary tumor site.

The lump in the axilla can surely be considered as either an inflammatory non-neoplastic process or a malignant one. Owing that the patient had diabetes mellitus as a predisposing factor led to the diagnosis of abscess in the axilla. However, no previous standard treatment for infection was able to heal this lesion for over 8 years and this lump has been producing blood for the past two years. Thus, a neoplastic or malignant process was considered. The radiology examination from MRI and PET-scan imaging confirmed this suspicion along with the findings of other metastatic sites other than the liver.

The histopathology examination showed malignant epithelial cells. The morphology of this tumor can be originated from several entities including pilomatrixoma, malignant pilomatrixoma, CCOT, and CEOT of the jaw. In short, this patient was thought to have either a skin/adnexal tumor or a jaw/odontogenic tumor.

Pilomatrix carcinoma has been identified as a tumor with a high local recurrence rate. Twenty-three percent of all cases were treated with wide excision and $83 \%$ of cases with simple excision developed recurrence. Therefore, wide excision should be the basic principle of treatment of this tumor with a surgical margin of $0.5 \mathrm{~cm}$ to $2 \mathrm{~cm}$. ${ }^{1}$ Pilomatrix carcinoma can spread to the lymph nodes and other internal organs such as the heart, lung, brain, liver, pancreas, kidney, adrenal gland, gaster, and submucosal colorectal. ${ }^{9}$ Pilomatrix carcinoma with lymph node metastasis should be treated with regional lymph node dissection. ${ }^{1}$
Radiotherapy is a good alternative in the case where wide excision approach could not be assessed and also as palliative treatment of systemic metastasis.

The definitive cause of PC is not known but some studies associate it to the $\beta$-catenin and WNT pathway. $\beta$-Catenin links cadherin to the actin cytoskeleton forming a cell to cell junction. ${ }^{4}$ Normally, $\beta$-catenin is phosphorylated and then degraded. Mutation of $\beta$-Catenin gene prevents phosphorylation of $\beta$-catenin and causes $\beta$-catenin accumulation. The accumulation reacts with the transcription factors namely the lymphoid enhancer factor-1/T-cell factor (Lef-1/Tcf) and activates the target genes (c-myc and cyclin D1) which then trigger the proliferation of matrix cells. $\beta$-catenin gene mutations were observed in at least $75 \%$ of pilomatrix carcinoma. ${ }^{4,5}$

Microscopically, the tumor is composed of poorly circumscribed atypical basaloid cells aggregation and can be accompanied by shadow/ghost cells and keratinous material. Calcification may be found in this keratinized material..$^{1,2,5}$ The basaloid cells have pleomorphic and hyperchromatic nuclei, prominent nucleoli, scant cytoplasm, and numerous atypical mitotic figures. ${ }^{1,2,5,6}$ The basaloid cells undergo apoptosis and transform into shadow cells. The shadow cells have characteristics such as pale, eosinophilic cytoplasm and discrete ghost nuclei. This tumor can extend throughout the dermis, the subcutaneous layer, and infiltrates the fascia, skeletal muscles, and bones. Some tumors may have vascular, perineural, and lymphatic invasion. Extensive central necrosis, desmoplastic stroma, and ulceration can be observed.

In term of demographic features, the patient, a 54 year old male, was similar to the demographic feature of pilomatrix carcinoma, pilomatrixoma, and CEOT. It is quite not suitable for CCOT since it was predominantly found in females with an average age of 20-40 years old. ${ }^{11,12}$ No findings to support a jaw lesion such as asymmetrical face, enlargement of the jaw, or mass inside the oral cavity nor prior mandibulectomy, suggested that this tumor is most likely belonged to the skin/adnexal tumor, especially pilomatrixoma or malignant pilomatrixoma.

The location and size of the axillar lump led to pilomatrixoma as a possible diagnosis, but the metastasis and survival time led to pilomatrix carcinoma. The literature stated that the common size of pilomatrixoma is around $0.5 \mathrm{~cm}$ to $3 \mathrm{~cm}$ and is located in head-neck regio and upper extremity.,13,14 Meanwhile, the pilomatrix carcinoma is commonly located in head-neck regio ranging from $0.5 \mathrm{~cm}$ 
to $20 \mathrm{~cm} \cdot{ }^{2,3,6}$ Pilomatrix carcinoma can appear as a transformation from pilomatrixoma or arises de novo as carcinoma. ${ }^{1}$ Nishioka et $a{ }^{15}$ reported a case of pilomatrix carcinoma arising from pilomatrixoma after 10 years as supporting information in this present case.

The immunohistochemistry staining of this case gave negative results for Hepar1, excluding a primary origin liver malignancy. Furthermore, it gave positive result on AE $1 / 3$ proving that it was an epithelial origin. Basaloid markers like CK5/6 and p63 were also positive, confirming that tumors are consisted of proliferative basaloid cells. Unfortunately, the more convincing markers for hair matrix and precortex keratin like $\mathrm{K} 35 / \mathrm{hHa} 5$ and $\mathrm{K} 31 / \mathrm{hHa} 1$ could not be performed due to the unavailability of the antibodies in our center. Histochemistry staining of congo red did not give a birefringence appearance. ${ }^{3,78}$ In CEOT, this stain can be expressed in the amyloid-like deposit. ${ }^{16,17}$

Once malignant pilomatrixoma or PC was diagnosed in this case, the next question to be solved was how did this tumor progressed. There are two hypothesis proposed: (1) History of the skin lump in the jaw area is a skin tumor. Excised yet never underwent a histology examination. Presumably it was a pilomatrixoma. Twelve years later it spread to the axilla and 20 years later it spread to the liver and other multiples sites; (2) Pilomatrixoma was the tumor in the axillar skin, developed 8 years ago. It transformed into malignant pilomatrixoma, producing blood, and never healed in the past two years. Then it spread to the liver and other multiple sites. This axillar lump had never been excised and had always been treated as infection although standard regiments have shown no improvement. Certainly no record of histology examination ever performed to this tumor. However, the previous skin lump of the jaw area was not related to present condition in this second hypothesis.

Those hypothesis will remain as theories since there are no other data available to confirm it. However, looking at those two called our attention that perhaps we can do more in treating this case. The previous skin lump in the jaw area should be sent for histopathology examination to obtain the actual diagnosis of the lump, which will be a useful information during patient follow up. The axillar lump should be excised, after a failure of standard regiment administration for 2 years, especially when it is quite big in size and showing symptoms for a possible malignancy. The patient should have been referred earlier to a center with an oncology team preventing a devastating outcome.

\section{REFERENCES}

1. Papadakis M, de Bree E, Floros N, Giannikaki E, Xekalou A,Manios A. Malignant pilomatrix: more malignant biological behavior than was considered in the past. Mol Clin Oncol 2017;6:415-8.

2. Margaritescu I, Chirita AD. Malignant pilomatrix. In: Rongioletti F, MargaritescuI, SmollerBR, eds. Rare Malignant Skin Tumors. 1st ed. New York: Springer-Verlag 2015.p.53-6.

3. Calonje E, Brenn T, Lazar AJ, Billings SD. Tumors of the hair follicle. In: McKee's Pathology of the Skin. $5^{\text {th }}$ ed. Cleveland, OH, USA: Elsevier 2020.p.1545-88.

4. KimYS, ShinDH, Choi JS, Kim KH. The immunohistochemistry patterns of the $\beta$-catenin expression in pilomatricoma. Ann Dermatol 2010;22:x.

5. Patterson JW. Cutaneous appendageal tumors. In: Practical Skin Pathology: A Diagnostic Approach. $19^{\text {th }}$ ed. Philadelphia: Elsevier 2013.p.357-99.

6. Ahmed TSS, Priore JD, Seykora JT. Tumors of the epidermal appendages. In: Elder DE, Elenitsas R, Johnson BL, Murphy GF, Xu X, eds. Lever's Histopathology of the Skin. ${ }^{10 t h}$ ed. Philadelphia. Lippincott Williams \& Wilkins 2009.p.851-931.

7. Patterson JW. Tumors of cutaneous appendages. In: Weedon's Skin Pathology. 4th ed. Elsevier 2016.p.903-65.

8. Raquena L, Crowson AN, Kaddu S, Kazakov DV, Michal M. Pilomatrical carcinoma. In: Elder DE, Massi D, Scolyer RA, Willemze R. WHO Classification of Skin Tumours. $4^{\text {th }}$ ed. France: IARC 2018.p.195-210.

9. Aherne NJ, Fitzpatrick DA, Gibbons D, Armstrong JG. Malignant pilomatrix presenting as an extra axial mass: clinicopathological features. Diagn Pathol 2008;3:47.

10. Hardisson D, Linares MD, Cuevas-Santos J, Contreras F. Malignant pilomatrix: a clinicopathologic study of six cases and review of the literature. Am J Dermatopathol 2001;23:394401.

11. Hellstein J. Odontogenesis, odontogenic cysts, and odontogenic tumors. In: Flint PW, Haughey BH, Lund V, Niparko JK, Robbins KT, Thomas JR, Lesperance MM, eds. Cummings Otolaryngology. $6^{\text {th }}$ ed. Philadelphia: Elsevier 2015.p.1323-44.

12. Gold L, Williams TP. Odontogenic tumors: surgical pathology and management. In: Fonseca RJ, ed. Oral and Maxillofacial Surgery. $3^{\text {rd }}$ ed. Missouri: Elsevier 2018.p.391-461.

13. Prieto VG, Shea CR, Celebi JT, Busam KJ. Adnexal tumors. In: Busam KJ, Goldblum JR, eds. Dermatopathology, $2^{\text {nd }}$ ed. Philadelphia: Elsevier 2016.p.388-446.

14. Jones C, Twoon M, Ho W, Portelli M, Robertson BF, Anderson W. Malignant pilomatrix: 12-year experience and review of the literature. J CutanPathol 2018;45:33-8.

15. Nishioka M, Tanemura A, Yamanaka T, Tani M, Miura $\mathrm{H}$, Asakura $\mathrm{M}$, et al. Malignant pilomatrix arising from pilomatricoma after 10-year senescent period: Immunohistochemistry analysis. J Dermatol 2010;37:735-9.

16. Hunter KD, Speight PM. The diagnostic usefulness of immunohistochemistry for odontogenic lesions. Head Neck Pathol 2014;8:392-9.

17. Lee SK, Kim YS. Current concepts and occurrence of epithelial odontogenic tumors: II. calcifying epithelial odontogenic tumor versus ghost cell odontogenic tumors derived from calcifying odontogenic cyst. Korean J Pathol 2014;48:175-87. 